\title{
Elaboration of an implementation approach of a condition-based maintenance through vibration analysis
}

\author{
El Mehdi Semma ${ }^{a}$, Ahmed Mousrij and Hassan Gziri \\ Laboratory of Mechanics, Industrial Management and Innovation, University of Hassan 1-Settat, Morocco
}

\begin{abstract}
Vibration analysis is a powerful and widely used tool in industry for monitoring rotating machinery. Despite the possibilities offered by the measuring equipment of vibration through technological progress, companies which practice Vibration Based Analysis (VBM) show performance below expectations in terms of machine availability. Our duty then is to develop an approach for the implementation of the VBM taking into consideration the keys to success and avoiding the causes of failure. We carried out an analysis of 30 years of practice of the VBM within a large Moroccan company in the chemical industry, through a collective approach called DCA (in French applied short diagnosis) and a survey among national and international experts in the field of the VBM. The synthesis of these studies has led us to propose a comprehensive and structured approach that comes in 5 phases: inventory, feasibility studies, preparation phase, implementation phase, evaluation and improvement phase.
\end{abstract}

\section{Introduction}

Vibration analysis is a technique of condition based maintenance particularly suitable for rotating machines. Its purpose is to monitor the operating status of these machines by analyzing vibration signals in some measurement points previously defined. Nevertheless, this technique is within the domain of specialists given the specific systems to be monitored with their probable defects, their requirements of cost and safety, diversity of the means of measuring and processing, as well as the difficulty of diagnosis of measured spectra. Despite the technological development of measurement tools and vibration analysis in recent years, there is a real gap between potentials of investigation and monitoring offered by these tools and most of the practices in the field. In addition, diagnosis and data interpretation of the vibration measurement is difficult to perform correctly. It all depends on the organization, experience and competence to properly perform the analysis [1]. To successfully establish an effective monitoring policy, a rigorous approach is then necessary to overcome these difficulties and avoid the causes of failure of its implementation [2]. Programs and procedures for implementation proposed by researchers address specific facilities and generally focus on the technical aspects [3]. Therefore, these procedures do not have a generic character making it possible to widespread their implementation. Many implemented programs relying on condition based maintenance using vibration analysis, produce results considered insufficient and below expectations. These programs of implementation merely face an organizational, logistical and cultural problem [4,5]. Even more that there are no standards addressing the implementation of condition based maintenance using vibration analysis.

\footnotetext{
${ }^{a}$ Corresponding author: e_semma@yahoo.fr
}

Amongst the maintenance policies whose implementation have been widely tackled in scientific researches and whose implantation was successful in various industries, we can mention the TPM (Total Productive Maintenance) [6-12] and RCM (Reliability centered Maintenance) [13-15] on the other side research on the implementation of condition-based maintenance is far less abundant.

Bengtsson [16] proposed an implantation approach of condition-based maintenance in four successive phases, the feasibility study, the analysis phase, the implementation phase and the evaluation phase. The author focuses on a set of key success factors in the implementation process such as management support, training of staff, good communication between the different stakeholders and motivation. Contrariwise, the suggested approach does not take into consideration the specificities of techniques used in condition-based maintenance (vibration analysis, oil analysis, Infrared thermography...). For example, the complexity of vibration analysis makes setting it up difficult in relation to the monitoring of operating parameters of industrial processes as a tool for monitoring [5].

Regarding the industrial case studies, few publications have addressed the managerial aspect either at the level of condition based maintenance programs or at the level of difficulties encountered in its implantation. Veldman [17] carried out an investigation within a Dutch industrial firm which practice condition-based maintenance. All these companies are taking a spontaneous approach toward condition-based maintenance focusing rather on the diagnosis based on the expertise of technicians. This is a reactive approach that proves to be sufficient when the reliability and availability demanded are easy to reach, but it can lead to crashes or unnecessary interventions. Furthermore, it is not clear how problems are identified and how decisions are made.

In addition, few studies have addressed the implementation of the Condition-based Maintenance using

This is an Open Access article distributed under the terms of the Creative Commons Attribution License 2.0, which permits unrestricted use, distribution, and reproduction in any medium, provided the original work is properly cited. 
vibration analysis. Courrech and Eshleman [18] propose a program to implement the VBM through eight successive steps focused on the technical aspect. However, this program disregards the managerial aspect that defines the actions of leadership by managers as well as the executives' commitment to the success of such maintenance. Boulenger and Pachaud [5] proposed an approach to implement the VBM into four phases: feasibility study, choices, starting the program and the practice of global monitoring. The approach neglects the organizational feasibility and does not emphasize on the study of the inventory prior to the feasibility study.

The objective of our study is to propose an approach to implement condition-based maintenance using Vibration Analysis dealing with different aspects: technical, operational, organizational and financial, which are necessary for the successful implantation of this type of maintenance. To develop a global approach taking into account the keys of success and avoiding the causes of failure, we conducted two complementary studies:

- An analysis of 30 years of practice of conditionbased maintenance using vibration analysis within a large Moroccan company in the field of chemical processing, via a collective approach called DCA (Short Autonomous Diagnostic) with stakeholders in the objective of identifying disabilities as well as key elements for a successful implantation of such maintenance policy.

- A survey has been conducted among national and international experts in the field of VBM for their views on the key factors for success as well as guidelines to follow to carry out a project to implant such a maintenance policy.

The synthesis of these studies allowed us to propose a global and structured approach that comes in 5 phases: inventory, feasibility studies, preparatory phase, setting up phase and evaluation and improvement phase.

In contrast to approaches encountered in the research which begin with a feasibility study, our approach offers previously, through studies carried out, an additional phase that describes the current situation to make an observation on the existing machinery fleet performance and the competencies of the maintenance personnel. It also proposes to assess the maturity of the organization of maintenance function before starting a project to implement the VBM.

\section{Analyses and evaluation of the VBM implementation in a large Moroccan chemical processing company}

Our study focused on a large Moroccan chemical processing company which has been practicing VBM for 30 years. Despite its long experience in Vibration Analysis and commitment of maintenance personnel, the results obtained by the establishment of the VBM are far from desired goals. As a first step, we carried out an audit on the effectiveness of the VBM practice. We were able to detect a lack of organization in the monitoring and vibration diagnosis department. A quantitative assessment of the
VBM program relevance during the years 2011 and 2012 helped us to record a total of $93 \%$ of mechanical failures that could be detected using vibration monitoring [19].

To diagnose the failure of implementation of the VBM practice within the studied company, we adopted the DCA approach which allowed us to make well-detailed analyses to identify, with all stakeholders, disabilities and opportunities to better achieve the basic ground of the VBM implementation.

\subsection{Presentation of the company studied}

The company studied is composed of three chemical processing plants. Each one is characterized by complex industrial processes operating a fleet of machines consisting of turbines, turbo-generators, turbochargers, crushers, pumps, blowers, gear systems and other large sizes machines. In order to master the availability of its facilities, the company has opted for a policy of decentralized maintenance integrating different types of maintenance. Being aware of the VBM importance for monitoring these facilities, the company has been committed to this approach over the last thirty years by raising necessary funds to buy high technology devices, subcontract measurement, vibration diagnosis and supervision for an eventual transfer of expertise.

\subsection{Presentation of the DCA approach}

Result of a collaborative and collective work, tested in different contexts, the DCA has been proven in terms of efficiency. It allows actually identifying, with remarkable control of time, a rich vision upon which strategic decisions can be made. It is a unique combination of six analyzes transforming individual concerns at a given time into a real common reflection on the future [20]. Before applying this approach, it is essential to have the support of management and to make the right choice of participants. This choice should cover all stakeholders in a VBM project to clearly identify obstacles, causes, risks and ways to improve the practice of vibration analysis in the studied company. Thus we have formed a working group made of 5 executive officers, 3 officers for preparation and planning as well as 2 representatives from mining sites.

The findings are in each analysis, slightly different and complementary. Their combination allows qualifying, reflecting and articulating the contributions of one another in a more rich and varied manner than could a regular dialogue between these persons [20].

\subsection{Deploying the DCA approach}

\subsubsection{Collecting information}

The first step in this process involves collecting of information from participants about their views on the current situation and the required future state of VBM within the company.

- Collection 1: Information about the current situation of VBM: We first collect information on sticky notes in six rounds to learn about the current state of the VBM. The number and color of sticky notes 


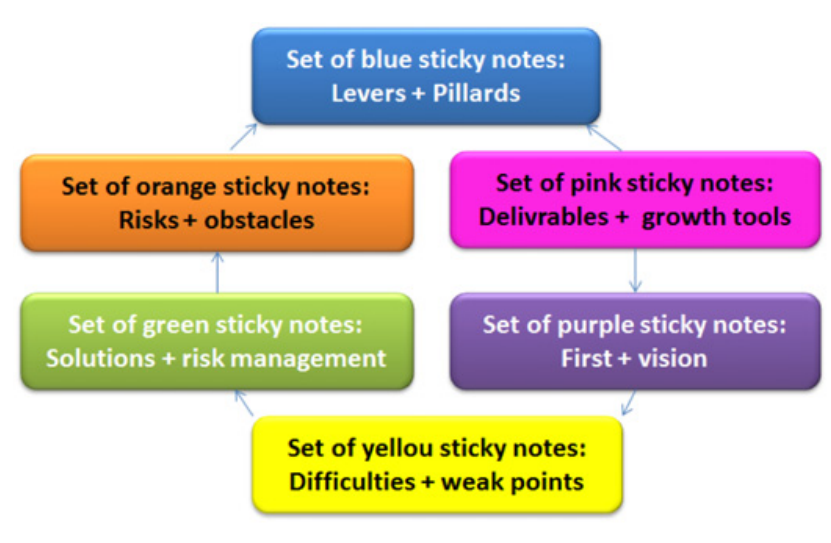

Figure 1. Gathering information collected into six groups.

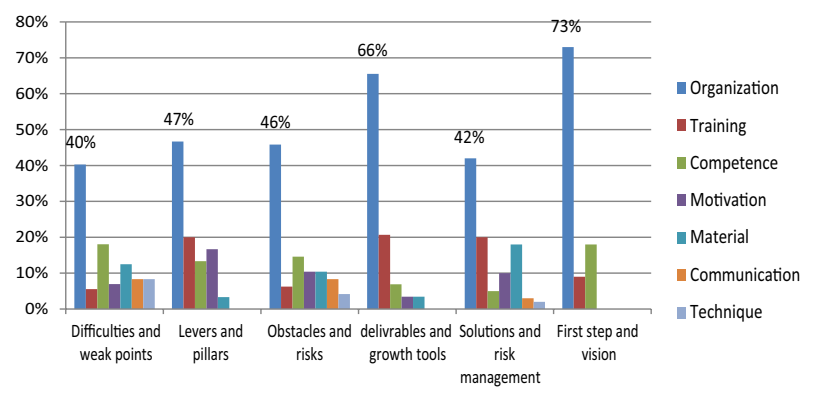

Figure 2. Synthesis of the direct analysis of data.

given to participants vary in each round. Participants fill in their sticky notes transcribing their ideas on issues grouped in Table 1.

- Collection 2: information about the required future situation of VBM: In the same manner, the second collection of information on sticky notes in six rounds allows us to imagine what we wish to achieve in three years in the field of the VBM (Table 2). At each round, the vision is enriched by pillars and components to support the required developments.

After gathering information on the current status and the desired status, the second phase will be devoted to the analysis of these data in order to deepen the diagnosis of the current VBM situation.

\subsubsection{Direct analysis of data}

We now address the first layer of analysis of this collection of information that we call "Direct Analysis" layer. We first put together the sticky notes produced by all participants. We sort them by colour, that is to say, by type of information (green with green, yellow with yellow and so on). We therefore obtain the six groups presented in Fig. 1.

A first reading of sticky notes allows us to identify the themes under which we will organize the data collected. The seven themes generated are: Communication, Competence, Training, Material, Motivation, Organization, and Technique. Color by color, we will sort and put together the sticky notes covering the same theme. The direct synthesis of this analysis is presented in Fig. 2.

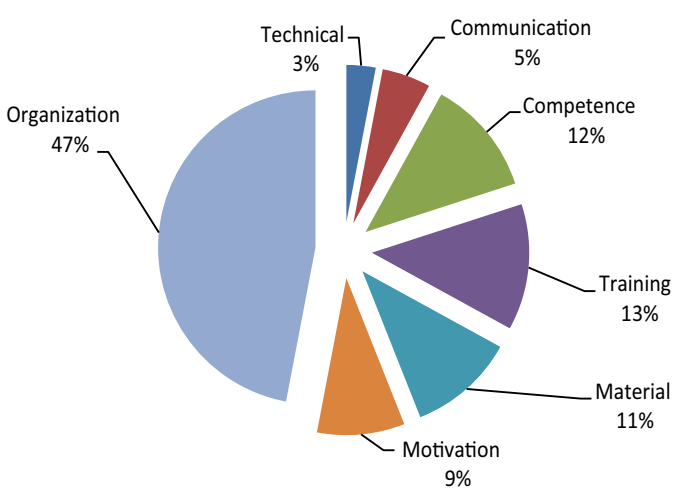

Figure 3. Synthesis of the thematic analysis of data.

Having identified the obstacles and difficulties to handle, perspectives, areas for improvement and the tools for success, Fig. 2 shows that the themes implicated in the failure of the establishment of the VBM within the company studied are: Organization, Training and Competence of personnel. In particular, the percentages illustrated in Fig. 2 show that the organization is the cornerstone of the success or failure of the VBM.

\subsubsection{Thematic analysis}

This analysis is simply called "thematic" because It includes data that has the same theme, whatever is the color of the sticky note. The challenge is to establish the broad concerns of the moment and to identify the first areas of work for the future. The synthesis of this thematic analysis is presented in Fig. 3 .

In line with the previous analysis, thematic analysis confirms that the organization is by far the key element of the successful implementation of the VBM.

\subsubsection{Analysis of the coverage of strengths and weaknesses}

We now address the third layer of analysis of the information collected. We call this one "analysis of the coverage of strengths and weaknesses".

We would like to determine the level of coverage of "difficulties mentioned" by "proposed solutions" and vice versa. It is whether the group that defines problems as finding solutions to these problems. It's about knowing whether the group that identifies the problems can find solutions too. we will therefore bring all the sticky notes that show the difficulties experienced and see whether all the sticky notes, containing the solutions or ways of working will bring a response or not. The synthesis of this analysis is presented in Table 3. Despite the number and variety of the problems mentioned, participants were also able to propose solutions. This analysis will allow us to identify the difficulties to overcome and to bring appropriate solutions during the development of the implementation approach of the VBM. 
Table 1. The information requested about the current situation of VBM.

\begin{tabular}{|l|l|l|}
\hline $\begin{array}{l}\text { Question asked in } \\
\text { each round }\end{array}$ & $\begin{array}{l}\text { Number of } \\
\text { sticky notes }\end{array}$ & $\begin{array}{l}\text { Color of sticky notes } \\
\text { sticky notes }\end{array}$ \\
\hline $\begin{array}{l}\text { Six difficulties facing } \\
\text { cell structuring of } \\
\text { vibration analysis? }\end{array}$ & 6 & Yellow \\
\hline $\begin{array}{l}\text { Five improvements } \\
\text { relative to the difficulties } \\
\text { of this type of maintenance }\end{array}$ & 5 & green \\
\hline $\begin{array}{l}\text { Four barriers that } \\
\text { prevent change despite } \\
\text { the existence of tracks }\end{array}$ & 4 & orange \\
\hline $\begin{array}{l}\text { Three levers that make, } \\
\text { despite the obstacles, } \\
\text { the existing vibration cells }\end{array}$ & 3 & blue \\
\hline $\begin{array}{l}\text { Identification of two deliverables } \\
\text { that can help function better } \\
\text { (any form of material: equipment, } \\
\text { space, objects, documents, } \\
\text { procedures, videos, media...) }\end{array}$ & 2 & pink \\
\hline $\begin{array}{l}\text { The first step towards } \\
\text { the right direction to } \\
\text { get out of the current situation }\end{array}$ & 1 & \\
\hline
\end{tabular}

Table 2. Required information on the future status of VBM.

\begin{tabular}{|l|l|l|}
\hline $\begin{array}{l}\text { Question asked in } \\
\text { each round }\end{array}$ & $\begin{array}{l}\text { Number of } \\
\text { sticky notes }\end{array}$ & $\begin{array}{l}\text { Color of } \\
\text { sticky notes }\end{array}$ \\
\hline $\begin{array}{l}\text { What would we become in } \\
3 \text { years in the field of } \\
\text { condition-based maintenance } \\
\text { using vibration analysis? }\end{array}$ & 1 & Purple \\
\hline $\begin{array}{l}\text { What will make } \\
\text { this success last? }\end{array}$ & 2 & Blue \\
\hline $\begin{array}{l}\text { What have we developed as } \\
\text { tools, abilities, methods, } \\
\text { recognitions, certification, skills, } \\
\text { habits or Agility to make } \\
\text { sustainable success? }\end{array}$ & 3 & Pink \\
\hline $\begin{array}{l}\text { When we will have achieved } \\
\text { this change, what should } \\
\text { we particularly pay attention } \\
\text { to? What are the risks involved? }\end{array}$ & 4 & \\
\hline $\begin{array}{l}\text { What should we do to } \\
\text { anticipate and deal with } \\
\text { these risks in order to } \\
\text { prepare ourselves for the best? }\end{array}$ & 5 & Orange \\
\hline $\begin{array}{l}\text { To achieve this goal, six } \\
\text { weak points that we must } \\
\text { learn to overcome by then }\end{array}$ & 6 & Green \\
\hline
\end{tabular}

\subsubsection{Analysis of risks and opportunities (SWOT analysis)}

The SWOT (Strengths, Weaknesses, Opportunities, and Threats) analysis tool widely used in many domains is used to analyze, diagnose and describe a state of existing situation.

For this analysis, we identified, together, all the possible "players, internal \& external", "opportunities" and "threats" for the four themes implicated in the analysis thematic: Organization, Training, Competence and equipment. It is about accurately identifying the possible influence of environment on our implementation project of VBM by an analysis of opportunities and threats related to our context. The SWOT matrix (Fig. 4) summarizes all the threats and opportunities for our project.

In conclusion, this industrial case study, allowed us to identify elements of failure and success in the 
Table 3. Synthesis of the analysis of the coverage of strengths and weaknesses.

\begin{tabular}{|l|l|}
\hline The outlined difficulties & Proposed Solutions \\
\hline No equipment history & Instruct machinery record \\
\hline Vibration cell is not organized & measurement Organization through sufficient time \\
\hline $\begin{array}{l}\text { Poor communication between the } \\
\text { inspection cell and the maintenance service }\end{array}$ & Develop communication \\
\hline Non mastery of vibration diagnosis & Advanced continuous Training \\
\hline Frequency of patrols is not well determined & Review the measurement frequency \\
\hline Lack of training & Extensive Continuous training \\
\hline Lack of vibration procedure & Development of procedures and formalizing processes involved \\
\hline A lack of training for subcontractors & work on subcontracting \\
\hline Lack of competence in the field & Train agents on work methods \\
\hline Lack of experts in vibration analysis & Proceed with the recruitment of the experts \\
\hline Lack of supervision & Transfer of expertise between the agents and supervisors \\
\hline Non motivation of inspectors & Motivate the team of the cell \\
\hline Poor equipment monitoring by vibration analysis & Review programs \\
\hline Improper handling of equipments & Mastery of measuring devices \\
\hline Difficult defects to detect & Mastery of vibration tools \\
\hline $\begin{array}{l}\text { Lack of responsibility to stop } \\
\text { the facilities to conduct measurements }\end{array}$ & Define responsibilities and powers \\
\hline
\end{tabular}

establishment of the VBM. To enrich our study, with the aim to develop a structured and comprehensive approach of the implantation of VBM, we carried out a survey among national and international experts to identify key factors and important decisions to consider during such a project.

\section{A survey among the experts in the field of VBM}

To carry out this survey, we solicited 15 national and international experts in the field of VBM to request their opinions on key factors and important decisions necessary for a successful implementation of a VBM. The questions are formulated as follows:

- What are the key success factors of implementation of condition-based maintenance using vibration analysis?

- What are the priority decisions to make to carry out an establishment of a condition-based maintenance using vibration analysis?

After collecting the responses, we proceeded to a count of views issued by our experts. We were able to identify 22 key factors and 9 priority decisions necessary for the successful implementation of the VBM. Then we classified the key factors (Table 5) and priority decisions (Table 6) by the number of respondents.

Synthesis of the survey: We grouped the key factors and important decisions in chronological order of the phases of a process for implementing an VBM approach we plan to develop. The 5 proposed phases are: Study of inventory, Feasibility study, preparatory Phase, establishment Phase, Evaluation and Improvement Phase. Unlike the VBM different approaches proposed in the literature, respondents' emphasis was on the importance of the first phase about the inventory to make a finding of the existing performance of the fleet of machines and competence of maintenance staff. The survey also showed
Table 4. Ranking of key factors according to the number of respondents.

\begin{tabular}{|l|r|}
\hline Factors & Number of respondents \\
\hline Evaluation and improvement & 7 \\
\hline Creation and update of machine records & 6 \\
\hline Status of existing in terms of resources & 5 \\
\hline Regular establishment of diagnosis reports & 5 \\
\hline Choice of equipments and measurement instruments & \\
\hline Choice of stakeholders & 5 \\
\hline Status of the existing in terms of equipments & 5 \\
\hline Selection of monitoring parameters & \\
\hline Establishment procedures & \\
\hline The management commitment & 3 \\
\hline Training and certifying & 3 \\
\hline Determining of responsibilities & 3 \\
\hline Bring experts for supervision & 3 \\
\hline Respect and update of maintenance calendar & 3 \\
\hline Training engineering & 3 \\
\hline Techno-economic study & 2 \\
\hline Stvdy of rotating machines' performance & 2 \\
\hline Study of organization maturity & \\
\hline Machine classification & \\
\hline Defects analysis & 2 \\
\hline Determine objectives & 2 \\
\hline Collection, processing and data archiving & 2 \\
\hline
\end{tabular}

the importance of the "Evaluation \& Improvement" phase for the establishment of an evaluation system at each stage of the process in a spirit of continuous improvement.

\section{Implementation approach of VBM}

The state of the art on the implementation of the VBM enriched by both studies, has enabled us to develop an approach articulated into five complementary 


\begin{tabular}{|c|c|c|}
\hline & Strengths & Weaknesses \\
\hline 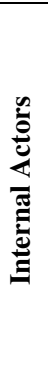 & $\begin{array}{l}\text { - Decision makers are aware of the importance of } \\
\text { skills' transfer between the agents and supervisors. } \\
\text { - } \quad \text { There is an experience of subtracting in the } \\
\text { company. } \\
\text { - } \quad \text { Decision makers give an importance to training. } \\
\text { - The most important for the compa ny is to } \\
\text { purchase profitable high technologic equipment. } \\
\text { - } \quad \text { Departments' managers favor practical training. } \\
\text { - There are audits which are scheduled in quality } \\
\text { management system. } \\
\text { - If high quality equipment appears in the market, } \\
\text { managers order it. }\end{array}$ & $\begin{array}{l}\text { - lack of organi zation and supervision, } \\
\text { - } \quad \text { a non organization of subcontracting, } \\
\text { there are no procedures that manage the relationship } \\
\text { between all the stakeholders in a facility (planning, } \\
\text { production agent, watchmen, intervention executive). } \\
\text { - The technical descriptions do not co ntain much specification } \\
\text { to order adequate equipment to the facilities. } \\
\text { - The training engineering is not done as it should. } \\
\text { - Wrong choice of auditors. } \\
\text { - The methods department, which is in charge of monitoring } \\
\text { the evolution of measuring equipments new techn ologies, } \\
\text { neglects technical monitoring. }\end{array}$ \\
\hline & Opportunities & Threats \\
\hline & $\begin{array}{l}\text { - There are experts who can transfer their } \\
\text { competences. } \\
\text { - } \quad \text { Supervising does not cost much. } \\
\text { - There are companies which are successful in } \\
\text { outsourcing of vibration measurements. } \\
\text { - The existence of a training plan for specific and } \\
\text { transversal themes. } \\
\text { - The existence of accredited suppliers on this } \\
\text { domain. } \\
\text { - There are experts who master the training } \\
\text { component. } \\
\text { The existence of specialized auditors in the } \\
\text { vibration domain. } \\
\text { The purchasing departm ent will not delay the } \\
\text { purchase of equipments. }\end{array}$ & 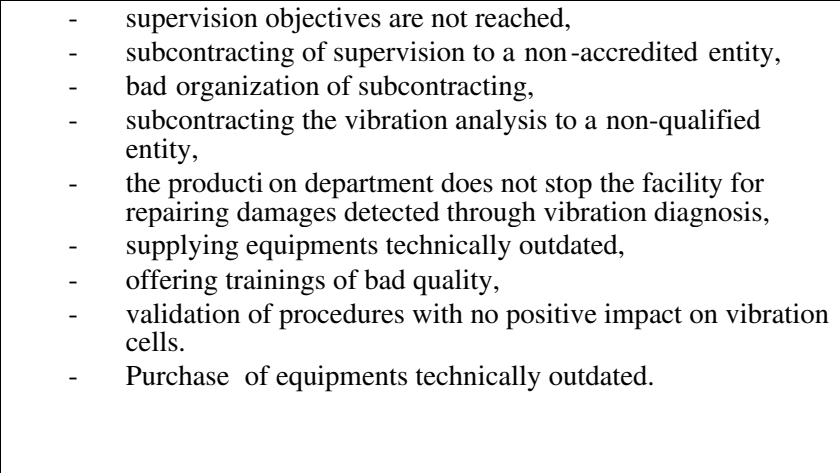 \\
\hline
\end{tabular}

Figure 4. SWOT Matrix.

Table 5. Ranking of key factors according to the number of respondents.

\begin{tabular}{|l|r|}
\hline Main decisions & $\begin{array}{l}\text { Number of } \\
\text { respondents }\end{array}$ \\
\hline Put a training plan to certify those in charge of Vibration Analysis & 5 \\
\hline Standardize the type of measurement devices and processing softwares & \\
\hline To conduct a regular monitoring of equipments using complete machine records & \\
\hline Start by monitoring critical machines & 5 \\
\hline Start the implantation through a study of the existing & 5 \\
\hline Program periodic meetings between all Vibration Analysis cells & 3 \\
\hline Start by supervision & 3 \\
\hline Respect measurement planning and exploit the feedback of machine analysis & 2 \\
\hline Apply procedures to establish evaluation and improvement & 2 \\
\hline
\end{tabular}

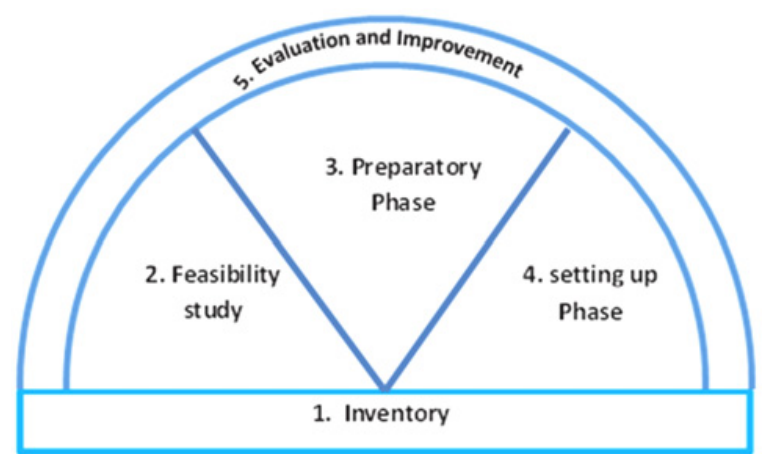

Figure 5. The different phases of the vibration analysis implementation approach.

phases, Fig. 5, to assist manufacturers in their project of establishing the VBM.

The Fig. 6 presents the synthesis of implantation of the proposed approach through flowchart.

\subsection{Phase 1: Inventory}

The first phase is to develop an inventory of existing situation aimed at collecting data on the history and performance of our machines and to establish a skills assessment of the maintenance staff. To do this, you must:

- Make a multi-criteria classification of rotating machines incorporating: the stop frequency, the downtimes, the cost of corrective maintenance and the impact of stopping the machine on production [21].

- Establish a historic of failures due to defects vibration (unbalance, misalignment, rolling failure...) components concerned with vibration analysis (bearings, shaft coupling, reducers...).

- Build a matrix of competencies which includes the actors of the VBM implementation project and their skills.

The result of this phase is to provide the management with objective information on the state of the existing system and will thereafter ensure regular monitoring of the performance of the machinery fleet and development of staff skills.

\subsection{Phase 2: Feasibility study}

This phase it is about checking the feasibility of the VBM implementation on the technical, organizational and financial plan.

- Technical feasibility: For this it is essential to define the percentage of machines involved in vibration analysis, knowing the speed of rotation (for small speeds below $250 \mathrm{rpm}$, vibration analysis is difficult to handle) and assess the risks and access difficulties to measurement 


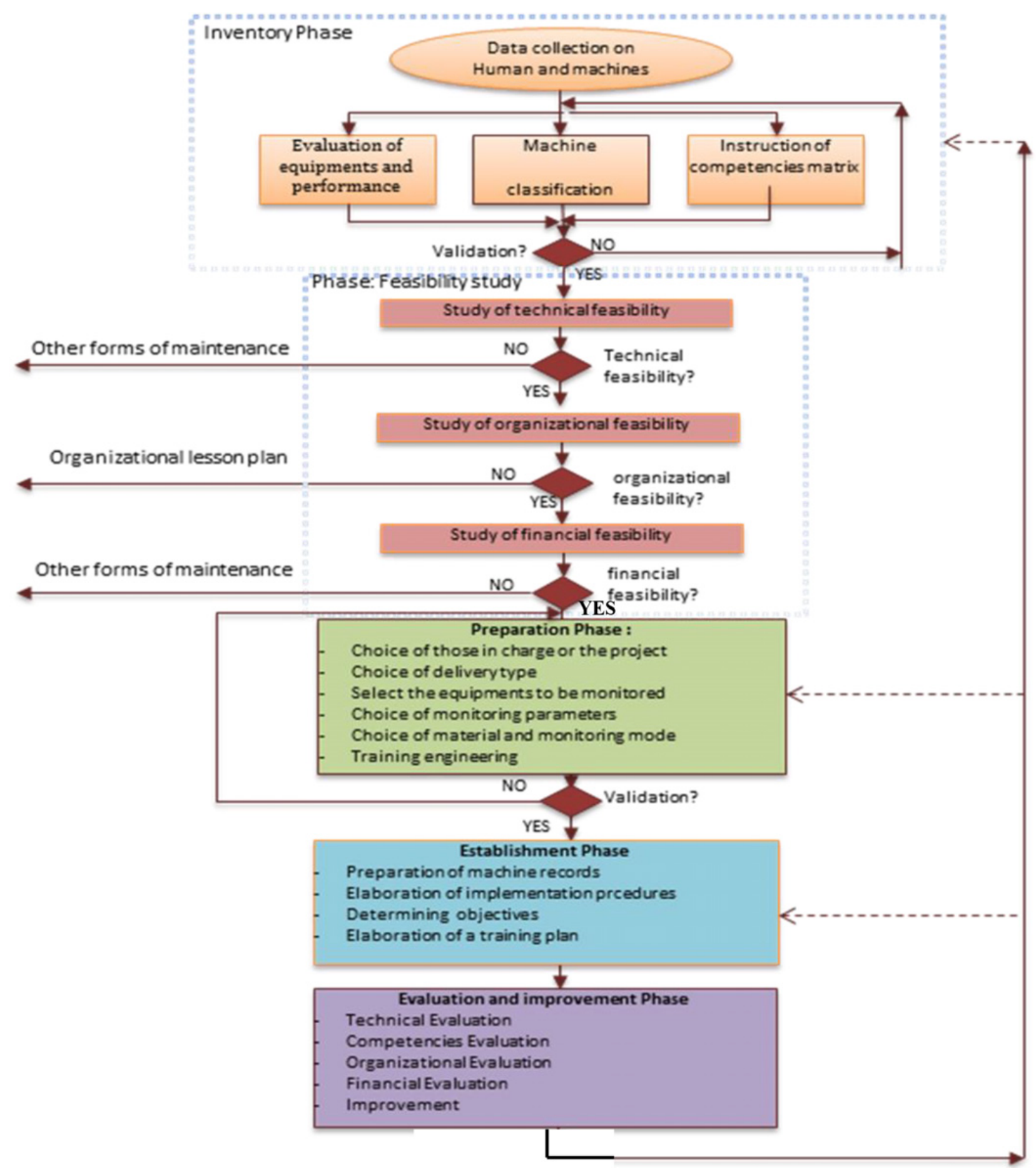

Figure 6. Implementation approach of the VBM.

points. If vibration analysis is not feasible technically, we must think of other tools maintenance.

- Organizational Feasibility: Before starting the implementation project, we must first assess the maturity of the organization of maintenance function within the company. The audit remains a powerful tool for the evaluation [22].

- Financial Feasibility: It is necessary to estimate the cost of monitoring and the cost of not monitoring (direct and indirect cost of breakdowns, equipments, training, scrap rates, loss of energy, and loss of customers...) to assess the VBM program profitability. In case of no profitability, we must think of some other form of maintenance.

\subsection{Phase 3: Preparatory phase}

Following the feasibility study, management must start the project by establishing the technical organization, human and financial organization and establishing a timetable for implementation. The major orientations shall be adopted in this phase can be summarized in the following points: 
- Defining roles and responsibilities of all actors for each stage of the project.

- Choice of performance: Depending on the size of fleet of machines and internal competencies, the company can choose between internalization or subcontracting all or part of the monitoring and diagnosis. If the VBM is a recent activity in the company subcontracting of support is recommended to ensure a transfer of expertise.

- Selection of critical equipments to be monitored according to multi-criteria classification established in the first phase.

- Selection of monitoring parameters: monitoring indicators, location of sensors, the measurement interval and configuration of tracking software should be defined at this stage.

- Choice of equipment and monitoring mode: The vibration monitoring equipment is related to fleet of machines (rotation speeds, the kinematic chain, etc.). For this reason, we should list for each machine, the sensors, the type of indicators for monitoring and diagnosis type (periodic or not). This determines, with the reliability required, the choice of the material.

- Engineering of training: it is here to exploit the skills matrix educated at the first phase to establish a training plan.

\subsection{Phase 4: Setting up phase}

After preparation, the setting up phase is followed by:

- The creation of records for machines that are needed to ensure proper monitoring of vibration. These machines folders should be considered as a basis for daily work and a reflex for any intervention of diagnosis and maintenance. Each file must contain at least:

- The original signature of each component monitored by the VBM,

- The original signature of each component monitored by the VBM,

- The history of breakdowns, cartography, failure analysis,

- The history of changes with their justifications,

- The MTBF and MTTR for each major component,

- The kinematic diagram and the measuring points.

- Establishing procedures that are essential for:

- Manage the matrix of skills and training of personnel involved in the vibration cell.

- Plan, measure, analyze and diagnose vibration defects.

- Follow up on support and subcontracting.

- Update machinery records.

- Measure and monitor various indicators.

- The establishment of performance indicators to quantify the success of the program and justify the different investments. Thereafter, management must define consistent objectives with the maintenance policy and the overall company policy and engage in achieving the required results in terms of reliability and equipment availability.
- Defining an ongoing training plan for the development of project stakeholders' competencies.

- Failure analysis means exceeding threshold must be followed by a thorough diagnosis to identify the severity of the defect and the root causes of the delay. The diagnostic results must be a feedback.

\subsection{Phase 5: Evaluation and improvement}

This is a very important phase which consists in establishing evaluation indicators at each stage of the implantation process to ensure the proper execution of the project and have a reliable evaluation system that allows managers to be part of a continuous improvement approach. The assessment should cover all aspects, technical, organizational, financial and project stakeholders' competencies. The choice of these indicators will be done in such manner to make the evaluation as objective as possible.

\section{Conclusions}

In this study, we developed an approach to implementing condition-based maintenance using vibration analysis. With the aim to propose a global and structured approach, we conducted two additional studies. First of all a very detailed analysis within a large company that has some thirty years of practice VBM by adopting the DCA approach in order to describe, analyze and diagnose VBM in this company. The analysis of the data collected from internal actors helped incriminate first poor organization in the failure of establishment of the VBM. As a result the SWOT analysis was used to synthesize, in the form of a matrix, threats and opportunities for the successful implementation of the VBM.

On the other hand, we carried out a survey among experts in the field of vibration analysis, this investigation allowed us to detect and prioritize the key factors and priority decisions to consider for a successful implantation project of the VBM.

These two studies have provided some answers to the problem that has initiated this research: What approach for successful establishment of the VBM within an industrial company? The approach we have adopted in our work then was to integrate practice and experience, across both studies, to develop a much focused approach on the technical side than other aspects, financial, organizational and managerial. The approach proposed is well articulated in five phases: inventory, feasibility studies, preparation phase, setting up phase and evaluation phase and improvement.

This research is in its very beginning and, following the studied company agreement we have just started the implementation of the various stages of the proposed approach. Our future work will focus on the technical aspects of implementation which aims to translate every step of our approach into a well detailed implementation process by developing procedures for setting up and indicators for measuring success guarantees of such a project. This is how we can concretely evaluate the performance of the proposed approach in order to demonstrate the relevance of the results and their reliability. Our ultimate goal is to 
provide an operational industrial tool that can help in the successful implementation of the VBM.

\section{References}

[1] C.I. Ugechi, E. Ogbonnaya, M. Lilly, S. Ogaji and S. Probert, Condition-Based Diagnostic Approach for Predicting the Maintenance equirements of Machinery. Engineering, 1 No. 3, pp. 177-187 (2009)

[2] R. Chaib, Contribution à l'optimisation de la maintenance conditionnelle par l'analyse vibratoire. These, University of Mentouri-Constantine, Algérie (2006)

[3] A. Garg and S. Deshmukh, Maintenance management: literature review and directions. Journal of Quality in Maintenance Engineering, 12(3), pp. 205-238 (2006)

[4] S. Belhour, Contribution à l'optimisation de la maintenance prédictive Par l'utilisation du logiciel Omnitrend (systeme on line) cas : Cimenterie Hamma Bouziane. These, University of MentouriConstantine, Algérie (2008)

[5] A. Boulenger and C. Pachaud, Analyse vibratoire en maintenance - Surveillance et diagnostic des machines, Dunod, Paris (2007)

[6] S. Nakajima, Introduction to TPM: Total Productive Maintenance. Cambridge, Productivity Press (1988)

[7] G. Chand and B. Shirvani, Implementation of TPM in Cellular Manufacture. Journal of Materials Processing Technology, 103(1), pp. 149-154 (2000)

[8] G. Cigolini and F. Turco, Total Productive Maintenance Practices: A Survey in Italy. Journal of Quality in Maintenance Engineering, 3(4), pp. 259-272 (1997)

[9] F. Cooke, Implementing TPM in Plant Maintenance: Some Organisational Barriers. International Journal of Quality \& Reliability Management, 17(9), pp. 1003-1016 (2000)

[10] M. Eti, S. Ogaji and S. Probert, Implementing Total Productive Maintenance in Nigerian Manufacturing Industries. Applied Energy, 79(4), pp. 385-401 (2004)
[11] H. Sun, R. Yam and N. Wai-Keung, The Implementation and Evaluation of Total Productive Maintenance (TPM) - An Action Case Study in a Hong Kong Manufacturing Company. International Journal of Advanced Manufacturing Technology, 22(3-4), pp. 224-228 (2003)

[12] A. Tsang and P. Chan, TPM Implementation In China: A Case Study. International, Journal of Quality \& Reliability Management, 17(2), pp. 144-157 (2000)

[13] R. Overman, RCM, Condition Monitoring, or Both. Maintenance Technology, pp. 25-28 (2002)

[14] J. Moubray, Reliability Centered Maintenance $R C M$ II (2nd edition), Industrial Press, New York (1997)

[15] G. Zwingelstein, La maintenance basée sur la fiabilité, Guide pratique d'application de la RMC, Editions HERMES, Paris (1996)

[16] M. Bengtsson, On condition based maintenance and its implementation in industrial setting. These, Mälardalen university, Suède (2007)

[17] J. Veldman, Process Improvement for Engineering and Maintenance Contractors. These, University of Groningen, The Netherlands (2011)

[18] J. Courrech and R.L. Eshleman, Condition monitoring of machinery. Fifth, New York (2002)

[19] E.M. Semma, A. Mousrij, A. Echchatbi and H. Gziri, Evaluation de la mise en ceuvre de la maintenance conditionnelle basée sur l'analyse vibratoire : Etude de cas. Workshop Optimisation des Systèmes, Amélioration Continue et Transformation des Entreprises. Marrakech - Maroc (2013)

[20] C.H. Russon, O. James, P. Bufferne, D. Mullender and D. Giguere, DCA stratégie mode d'emploi version 10.0. IFEAS - Editions Scientifiques \& Techniques, Paris (2010)

[21] H. Stadhouders, A Framework for implementing Condition Based Maintenance based on Operational Data. These, Eindhoven University of Technology, Netherlands (2011)

[22] G. Laloux, Management de la maintenance selon l'ISO 9001: 2008, AFNOR, France (2009) 